\title{
The Legal Foundation of Religious Associations in Poland in the Interwar Period and Currently and Examples of their Activities
}

\begin{abstract}
After the First World War the newly reborn Polish state needed huge financial expenditures to manage the immense poverty, unemployment, and deprivation. But after the war the state couldn't manage such problems alone, because of the lack of sufficient resources to be able to meet the needs of those affected. That is why numerous charitable organizations were being established. They were created out of religious inspiration by groups of the faithful or specifically by the churches and other denominations. The most numerous group of associations was that established by the Catholic Church - the largest denomination in Poland. The associations were regulated by the Law on Associations of 1932, prior to which they were subject to the various post-partition laws in the three sectors. But in most cases the Law on Associations didn't distinguish separate regulations for religious associations. In contemporary Poland it is the Law on Associations of 1989 that regulates the creation of associations. It further divides associations into two main groups - registered and non-registered. It will be the law which governs those secular associations which are established for religious purposes. It applies to denominational associations with some exceptions, but doesn't apply at all to those established by churches and other denominations (that is, ecclesiastical associations). Currently, similarly to the interwar period, the purposes of specified groups of associations haven't changed - the main reason for their existence is to engage in undertaking charitable activities.
\end{abstract}

Key words: the interwar period, law on associations, denominational associations, ecclesiastical associations, churches and other denominations.

\section{Introduction: Constitutional guarantees of the right to create associations}

The freedom of conscience and religion is one of the basic human rights that derive from fundamental human dignity. An important manifestation of this freedom is the opportunity to associate for religious purposes. In the interwar period in Poland the main 
regulation that guaranteed rights and freedoms could be found in the fundamental laws - the constitution of $17^{\text {th }}$ March $1921^{1}$ and that of $23^{\text {rd }}$ April $1935 .^{2}$ In its article 104 the March constitution granted each citizen the freedom of expression of his thoughts and beliefs provided that such expression didn't violate any applicable laws. That freedom was linked to the citizen's right to create coalitions, unions, and associations. These freedoms were expressed in article 108. Thanks to article 111, which granted all citizens freedom of conscience and religion, these associations could be based on religious principles. Based on this freedom citizens were allowed to confess their beliefs in public or in private, and could participate in religious ceremonies, but they were restricted from violating public order and decency on a pretext of religious license. On the one hand faith and religious beliefs might not have led to any limitation of civil rights - which could constitute discrimination; but on the other hand faith could not be used as a pretext to fail to, or refuse to, fulfill public duties and obligations. The citizens had the right to create associations and to be members of them, including those which were based on religious beliefs. From the points of view of the churches and various other denominations, the constitution granted the Catholic Church a privileged position among the equal rights of denominations and recognized its autonomy (article 114). This autonomy authorized the Catholic Church to create associations and govern them. The codification of relations between the state and the Catholic Church was to be specified in a subsequent bilateral agreement - a concordat - that needed to be approved by parliament. That agreement was concluded on $10^{\text {th }}$ February $1925 .{ }^{3}$ Similarly, denominations which were recognized by the state had the right to self-management of their own internal affairs, and the right to the possession and management of their own foundations and funds or establishments instituted for religious and charitable purposes (article 113). After arriving at agreement with the representatives of the churches and other denominations the condition under which the state would recognize denominations in the act that had been issued was their compliance with the law (articles 115, 116). In the interwar period individual acts were issued for: the Orthodox Church in Poland, the Jewish Communities, the Evangelical Church of the Augsburg Confession, the non-hierarchical Eastern Old Believers' Church, the Muslim Religious Union, and the Karaim Religious Union. ${ }^{4}$ In article 5 paragraph 2 the next constitution, that of 1935, concisely granted citizens freedom of conscience, freedom of speech, and the freedom to form associations. In paragraph 3 it established that the concept of the common good could be used to impose limits on these freedoms. But articles 99, 109 to 118 , and 120 of the March constitution remained in force in article 81 paragraph 2 of the 1935 constitution. In this way the April constitution preserved the autonomy of churches and other legally recognized denominations, while the Catholic Church held

\footnotetext{
1 Journal of Laws [Dziennik Ustaw] No. 44, item 267 as amended.

2 Journal of Laws [Dziennik Ustaw] No. 30, item 227.

3 Journal of Laws [Dziennik Ustaw] No. 72, item 501. S. Łukomski, Konkordat zawarty dnia 10 lutego 1925 r. pomiędzy Stolica Apostolska a Rzeczapospolita Polska, Łomża 1934.

4 H. Misztal, Historia relacji państwo - Kościót w Polsce [in:] A. Mezglewski, H. Misztal, P. Stanisz, Prawo wyznaniowe, Warszawa 2011, p. 28-29. The legal situation of the Catholic Church was regulated by concordat; whereas those of several other churches and other denominations in the interwar period were based on post-partition regulations. Some of them, for example Holy Scripture Researchers or Methodists had been deemed "intolerable." See: ibidem.
} 
the position of primus inter pares. But the April constitution did not adopt article 108 of March constitution - the article that granted the right to create associations and unions, and the right to form coalitions. The April constitution replaced this article with the very short article 5, which granted citizens the right of assembly.

The April constitution had been replaced by the constitution of $22^{\text {nd }}$ July 1952..$^{5}$ That constitution were enacted in so-called Polish People's Republic. That period in the Polish history is omitted in the article because despite the fact, that above mentioned constitution guaranteed all citizens the freedom of conscience and religion (article 70), in real the state authorities did not respect the constitutional freedom of conscience and religion and the freedom of associations (article 72). ${ }^{6}$ The associations, especially those created because of religious purposes were rather liquidated. ${ }^{7}$

The constitution of $2^{\text {nd }}$ April $1997^{8}$ replaced the constitution of 1952, and is still in force. The constitution of 1997 in article 53 guarantees everyone, not only the citizens, the freedom of conscience and religion. The article 53 contains only exemplification of the way in which this freedom of religion may be expressed; for example by taking part in religious worship, practice of religion or prayer. The limitation of expressing religious beliefs may be introduced only by the law and only of the reason to protect state security, public order, health, morality and other people's rights and freedoms. The freedom of association is expressed in the Polish constitution in articles 12 and 58. Constitution guarantees everyone the right to associate. And because of the article 53 mentioned above, those associations may also be created on the grounds of religious beliefs. The constitution of 1997 in article 25 paragraph 5 states that relations between the state and the churches and other denominations (except Catholic Church) will based on law enacted on the ground of agreement concluded between representatives of the church/denomination and the representatives of the Council of Ministers. Nowadays there are fifteen acts of that kind. The legal situation of the Catholic Church in Poland has been regulated both in the Law on the relationship between the state and the Catholic Church in the Republic of Poland and in the concordat concluded on $28^{\text {th }}$ July $1993^{9}$ (such regulation of the situation of Catholic Church in Poland was determined in the constitution, article 25 paragraph 4). In contrast to the character of the concordat of 1925 , the current concordat in article 19 grants the laity the right to associate in accordance with, and for the purposes specified in, canon law. At the same time it is specified that

5 Journal of Laws [Dziennik Ustaw] No. 33, item 232, as amended (consolidated text: Journal of Laws [Dziennik Ustaw] of 1976, No. 7, item 36).

6 A. Szymaniak, Prawa obywatelskie w konstytucjach z 1952 r. i 1997 r. Analiza porównawcza, "Ruch prawniczy, ekonomiczny i socjologiczny" 2001, Y. LXIII, Vol. 3, p. 33.

7 See more about the changes of Law on Associations of 1932 made by the authorities of the Polish People's Republic: M. Ordon, Modification of the legal basis of the activity of religious orders in Poland introduced by the communist authorities in 1949, "Studia z Prawa Wyznaniowego" 2014, Vol. 17, pp. 193-204. About the liquidation of the religious associations in Poland in the period of People's Republic see, ex.: idem, Bezprawne przejęcie przez władze komunistyczne majątku Stowarzyszenia "Opieka nad Dziewczętami pod wezwaniem św. Józefa" w Krakowie, "Studia z Prawa Wyznaniowego" 2001, Vol. 2, pp. 127-148; idem, Ograniczenia wolności zrzeszania się w odniesieniu do organizacji Kościoła katolickiego w Polsce Ludowej [in:] E. Kozerska, P. Sadowski, A. Szymański (eds.), Idea wolności w ujęciu historycznym i prawnym. Wybrane zagadnienia, Toruń 2010, pp. 143-154.

8 Journal of Laws [Dziennik Ustaw] No. 78, item 483 as amended.

9 Journal of Laws [Dziennik Ustaw] of 1998 No. 51, item 318. 
whenever the activities of the associations venture into the public domain they are also subject to Polish law. ${ }^{10}$

\section{Law on associations in the interwar period}

In the field of freedom of association in the Second Republic in Poland the legal structure that had been left by the invaders prevailed until 1932. The act of $19^{\text {th }}$ April 1908 had guaranteed the right to create associations in the former Prussian partition sector. The act permitted a group of a minimum of at least seven citizens to establish an association under the condition that the aims of the association couldn't be contrary to the law. The associations needed to be registered with the judiciary by the court of appropriate jurisdiction. In the former Russian partition sector freedom of association had been based on the decree of $4^{\text {th }} / 17^{\text {th }}$ March 1906 , which introduced temporary regulations concerning associations and unions. This decree had defined an association as an organization consisting of an unspecified number of members, which aims to achieve goals that are positive to the society overall, and not only for the members of association. Moreover, the decree prohibited the creation of secret associations. The associations were divided into those which were registered by the provincial or municipal office for associations, and those which were registered by notification with the governor. The former had legal personality, the latter did not. But the terms of the decree did not apply to academic or religious associations. ${ }^{11}$ In the former Austrian partition sector the rules which had been determined by the act of $15^{\text {th }}$ November 1867 for the establishment of associations remained in force until 1932. ${ }^{12}$ The conditions under which associations could be created were notification to the national authority, and submission of the organizational statutes. But paragraph $3 \mathrm{a}$ of that act had excluded congregations, religious associations, and monastic orders from its application.

After 1918 new regulations were enacted which adapted post-partition laws of association to the new socio-political conditions. ${ }^{13}$ But the freedom to form associations granted each citizen by the constitution was reflected in the uniform Law on Associations for all Poland. On 27 $7^{\text {th }}$ October 1932, 14 years after Poland had regained its independence, the Law on Associations was enacted by regulation of the President

10 More about associations founded on the basis of the Code of Canon Law of 1983 see: J. Krukowski, Stowarzyszenia wiernych chrześcijan [in:] J. Dyduch, W. Góralski, E. Górecki, J. Krukowski, M. Sitarz, Komentarz do Kodeksu Prawa Kanonicznego, vol. II/1, Lud Boży, Pallottinum 2005, pp. 123-155; K. Krzysztofek, Stowarzyszenia Kościoła Katolickiego w świetle norm prawa polskiego i prawa kanonicznego [in:] D. Walencik (ed.), Prawo wyznaniowe w Polsce (1989-2009). Analizy - dyskusje - postulaty, KatowiceBielsko-Biała 2009, pp. 117-123.

11 E. Smoktunowicz, Prawo zrzeszania się w Polsce, Warszawa 1992, pp. 22-26; S. Szypuliński, Prawo o stowarzyszeniach, Poznań 1997, pp. 11-12; P. Suski, Stowarzyszenia i fundacje, Warszawa 2005, pp. 21-24.

12 Journal of State Laws [Dziennik Ustaw Państwa] No. 134, see: J. Piwocki, W. Stesłowicz, J. Münz, Zbiór ustaw i rozporządzeń administracyjnych, t. I, Lwów 1909, pp. 185-207.

13 See more: K. Krzysztofek, Stowarzyszenia katolickie w Krakowie w latach 1918-1939. Studium historycznoprawne, Kraków 2014, pp. 56-59.

Artykuły - Articles 
of the Republic of Poland. ${ }^{14}$ This act introduced uniform rules for the establishment of associations in Poland. The regulation defined an association as a voluntary, permanent, non-profit society (article 1). The act also distinguished two kinds of associations. The first was the ordinary associations which could be created by a group of a minimum of at least three persons who notified the starosta - the chief administrative official of the powiat (local district) - (article 12 excepted the Silesian region from the provisions of this act). The second was the registered associations which could be created by a group of at least fifteen persons, which applied for registration to the governor of the province through the starosta who was designated as being the competent authority. These were required to submit their written application for registration together with the organization's proposed statutes (article 19). But associations that were created based on religious grounds were exempted from these regulations. Article 9 stated: "The regulations of this law do not apply to: a) monastic orders and spiritual congregations, and other associations whose only and specific reason is to conduct religious worship, legally recognized churches, and denominations" [English translation by the author]. Thus, only religious associations formed by churches and other denominations which were not otherwise legally recognized, and those created by legally recognized associations, but not only and not specifically to practice religious activities, were created in accordance with the Law on Associations. ${ }^{15}$ Additionally, article 10 allowed for the Council of Ministers, at the request of the Minister of the Interior, acting in consultation with the Minister for Religious Affairs and Public Enlightenment, to regulate the creation of associations by the legally recognized ecclesiastical and denominational associations, even if those associations would not be acting solely and directly for the purpose of the exercise of religious activities. Based on that article the Council of Ministers issued the Regulation of $28^{\text {th }}$ January 1934 concerning associations designed exclusively for the religious purposes of the Catholic Church. ${ }^{16}$ The regulation modified the rules of the Law on Associations for those Catholic associations, which due to the subject of their activity, didn't otherwise qualify for an exemption from the provisions of the Regulation of 1932. The main objective of these associations was the spreading of Christian principles, and they were required to be under a bishop's supervision. When they complied with these conditions, they were subject to the Law on Associations, but the new act granted them certain exceptions. First of all they were permitted to introduce the principle of absolute obedience to the authority of the association. Secondly, as ordinary associations they could create branches and associated legal persons, form unions of associations, and accept contributions from the general public and public institutions grants. This meant that in this respect ordinary associations received the same privileges as registered ones. Any refusal by any state authority to fund that kind of association might be based solely on the condition non-compliance with the law, and the state authorities were required to inform the diocesan bishops via governors about any such non-compliance with the law

14 Journal of Laws [Dziennik Ustaw] No. 94, item 808 as amended. See: J.S. Langrod, Polskie prawo o stowarzyszeniach; uwagi krytyczne, Kraków 1934.

15 See more: M. Ordon, Prawo o stowarzyszeniach jako instrument antykościelnej polityki władz komunistycznych w okresie Polski Ludowej - zarys problemu, "Studia z Prawa Wyznaniowego" 2002, Vol. 4, pp. 94-95; K. Krzysztofek, Stowarzyszenia katolickie..., pp. 59-73.

16 Journal of Laws [Dziennik Ustaw] No. 9, item 72. 
that they might observe. The same rules concerned the unions of associations designed exclusively for the religious purposes of the Catholic Church, even if some affiliated associations did not come under the rules of the Regulation of 1934. In order for an association to take advantage of the exception provided for in the 1934 regulation the diocesan bishop needed to notify the governor. By that notification a bishop confirmed his consent for the establishment of an association, or he presented his approval for those already existing. The question was how to define what exactly constituted an association designed exclusively for the religious purposes of the Catholic Church. They might be restricted to working only for those purposes mentioned in the 1934 regulation (often the state authority would specify this otherwise availing themselves of those privileges) or in addition they might be permitted to engage in charitable activities. The legislature didn't resolve this issue in the Regulation of 1934.

Therefore, a question arises as to what kind of associations existed in Poland in the interwar period. The existing regulation - the Law on Associations - used expressions like "monastic orders," "spiritual congregations," and "other associations established to engage in religious activities within the legally recognized churches and denominations." The Regulation of 1934 introduced an additional category - associations designed exclusively for the religious purposes of the Catholic Church.

But the Regulation lacked definitions of those associations, and there was no distinction between associations established according to canon law (internal law of the Church) and those established by the Catholic laity based on secular law and enjoying approval of church authorities. The definition of associations designed exclusively for the religious purposes of the Catholic Church was close to those mentioned above, but they can be equated neither to modern denominational associations, nor to ecclesiastical and secular associations having religious aims.

As has been mentioned above, in the Second Polish Republic individual laws were drafted that regulated six of the existing churches and other denominations. In contrast to the legal situation of the Orthodox Church in Poland and the Jewish Communities the decrees that regulated the other four churches and other denominations did not include a right to establish religious associations. Paragraph 1 of Article 1 of the decree promulgated by the President of the Republic of Poland on $25^{\text {th }}$ November 1936 regulated the legal situation of the Evangelical Church of the Augsburg Confession, ${ }^{17}$ recognizing its right to full freedom to profess its faith and practice its religious observances. Beyond this, provisions in article 10 recognized its right to possess and manage its foundations and finances, and to possess institutions established for religious, scientific, and charitable purposes. Article 2 of the Law of $21^{\text {st }}$ April 1936 regulated the legal situation of the Karaim Religious Union. ${ }^{18}$ The Union was granted the rights to govern itself according to its own rules within the limits of applicable state law, and, under article 12, to create Karaim religious communes in Poland which themselves could establish charitable institutions. The law of $21^{\text {st }}$ April 1936 regulated the legal situation of the Muslim Religious Union, ${ }^{19}$ granting it the right to associate only indirectly - this freedom may be derived only from article 2 that guaranteed the Muslim Union autonomy. The same

17 Journal of Laws [Dziennik Ustaw] No. 88, item 613.

18 Journal of Laws [Dziennik Ustaw] No. 30, item 241.

19 Journal of Laws [Dziennik Ustaw] No. 30, item 240. 
applies to the non-hierarchical Eastern Old Believers' Church, ${ }^{20}$ whose legal situation was regulated by the Regulation of the President of the Republic of Poland of $22^{\text {nd }}$ March 1928. Also, the Orthodox Church in Poland (its legal situation was regulated by the decree of the President of the Republic of Poland of $18^{\text {th }}$ November $1938^{21}$ ) had the right to govern itself according to its own rules (article 1 paragraph 2). But in addition, the Orthodox Church in Poland was granted the right to create orthodox brotherhoods in its parishes. The brotherhoods in turn operated according to the Law on Associations. The aims of those brotherhoods were: development of religious life, education, maintaining the places of worship, cooperation in arranging services, and engaging in charitable activities (these objectives derived from the Internal Statute of the Orthodox Church in Poland ${ }^{22}$ ). The term "denominational association" appeared in the Regulation of the President of the Republic of Poland of $14^{\text {th }}$ October 1927 which regulated the legal situation of the Jewish Communities (this law was in force throughout Polish territory, with the exception of the Silesia region ${ }^{23}$ ). Denominational associations were permitted to be established in each large religious community with the permission of the supervisory authority - the Minister of Religious Affairs and Public Enlightenment (article 50). The purpose of these kinds of associations was, for example, the possession and maintenance of cemeteries and synagogues, etc. (article 32).

The legal situation of the Catholic Church in Poland in the interwar period wasn't regulated by decree or regulation, but was based on an international agreement with the Holy See - a concordat. However, this agreement expressed only the Church's rights, not the freedoms of the laity, such as a right to establish religious associations. The entitlement to create religious associations results from article I, which guaranteed the Catholic Church freedom of jurisdiction in all its rites, administration, and boards of its own affairs and properties in accordance with divine and canon law. The Code of Canon Law of 1917, which was in force at the time of the conclusion of the concordat, distinguished different types of associations, both those created by the Church membership, and those created by the Church authorities - i.e. those established, or at least endorsed, by the Church. ${ }^{24}$

20 Journal of Laws [Dziennik Ustaw] No. 38, item 363.

21 Journal of Laws [Dziennik Ustaw] No. 88, item 597.

22 The statute had been approved by the Council of Ministers on $10^{\text {th }}$ December 1938 , Journal of Laws No. 103, item 679.

23 Journal of Laws [Dziennik Ustaw] No. 91, item 818. This Regulation had been included in the Regulation of $5^{\text {th }}$ April 1928 of the Minister of Religious Affairs and Public Enlightenment, Journal of Laws [Dziennik Ustaw] No. 52, item 500.

24 See more about different kinds of associations mentioned in the Code of Canon Law of 1917: I. Grabowski, Prawo kanoniczne wedtug nowego kodeksu, Lwów 1927, pp. 329-337; F. Bączkowicz, Prawo kanoniczne, podręcznik dla duchowieństwa, Vol. I, Opole 1957, pp. 762-779. 


\section{Law on associations in the modern period}

Currently, it is the Act of $7^{\text {th }}$ April 1989 - the Law on Associations - which regulates the right to associate. ${ }^{25}$ It defines associations as voluntary, self-governing, non-profit, permanent societies (article 2 paragraph 1). As it was said, the right to associate follows from the constitution ${ }^{26}$ which guarantees in article 12 the citizens' prerogative to establish and function in associations. The constitutional right to associate is further developed in the above-mentioned Law on Associations of 1989, which guarantees to Polish citizens who have full legal capacity the right to create associations. It further divided associations into two kinds: ordinary and registered (the same as was done in Law of 1932). Registered associations (from $20^{\text {th }}$ May 2016 must be founded by at least 7 persons) are registered in the National Court Register, and by virtue of registration, they are granted legal personality, and may engage in appropriate activities and establish branch offices. Ordinary associations can be created by as few as three persons and don't need to register, but they must notify the starosta of the act of the creation of the association. After $20^{\text {th }}$ May 2016 ordinary associations were granted partial legal personality in their functioning, and in respect of legal status they are similar to those registered, but ordinary associations still do not have the right to conduct economic activity or establish branch offices. However, article 7 paragraph 1 point 2 excludes churches and other denominations and their legal entities from the application of the Law on Associations, and point 3 excludes religious associations existing within churches and other denominations whose legal situation is regulated by those legal acts which determine relations between the state and the churches and other denominations. But in aspects which aren't regulated by those individual acts, the Law on Associations applies to those organizations mentioned in article 7 paragraph 1 point 3 of the Law on Associations. The associations mentioned in article 7 paragraph 1 point 3 can be divided into denominational associations and ecclesiastical associations. ${ }^{27}$ That division results from terminology used by the individual acts to regulate the situation of churches and other denominations in Poland. There are currently fifteen acts of this kind, therefore fifteen churches and other denominations have their legal status regulated individually. Three of the fifteen acts that are now in force were issued in the interwar period. There are acts/decrees concerning: the non-hierarchical Eastern Old Believers' Church, the Muslim Religious Union, and the Karaim Religious Union. However, these acts do not include provisions which regulate the right to associate for religious purposes, and the Karaims, Muslims, and Old Believers in Poland may establish associations based on those general principles which apply to non-religious based organizations, and those based on rights granted in article 12 of the Constitution, and the Law on the Guarantees of Freedom of Conscience

25 Journal of Laws [Dziennik Ustaw] No. 20, item 104 as amended (consolidated text: Journal of Laws [Dziennik Ustaw] of 2017, item 210).

${ }^{26}$ Constitution of the Republic of Poland of $2^{\text {nd }}$ April 1997, Journal of Laws [Dziennik Ustaw] No. 78, item 483 as amended.

27 P. Sarnecki, Prawo o stowarzyszeniach. Komentarz, ed. II, Zakamycze 2002, pp. 38-39. 
and Religion of $1989 .{ }^{28}$ The right to associate for religious purposes is a derivative of the freedom of conscience and religion which is guaranteed to everyone in article 53 paragraph 1 of the Polish Constitution. In this manner, the lack of a clear expression of that right in individual acts doesn't exclude the exercise thereof.

The last twelve individual acts concern: the Catholic Church, ${ }^{29}$ the Orthodox Church in Poland ${ }^{30}$ the Evangelical Reformed Church, ${ }^{31}$ the Evangelical Church of the Augsburg Confession, ${ }^{32}$ the Evangelical Methodist Church, ${ }^{33}$ the Old Catholic Mariavite Church, ${ }^{34}$ the Catholic Mariavite Church ${ }^{35}$ the Polish National Catholic Church ${ }^{36}$ the Seventh Day Adventist Church, ${ }^{37}$ the Baptist Church, ${ }^{38}$ the Union of Jewish Religious Communities $^{39}$ and the Pentecostal Church. ${ }^{40}$ On the basis of these individual Laws three kinds of associations can be differentiated: denominational associations, ecclesiastical associations, and secular associations established for religious purposes. Denominational associations are established with the approval of the ecclesiastical authorities in seven churches and other denominations. There are: Catholic, Orthodox, Evangelical-Augsburg, Baptist, Adventist, Jewish, and Pentecostal associations. Those created in the Orthodox Church are called orthodox brotherhoods. Together with giving its approval for the establishment of the denominational associations, the ecclesiastical authority must designate its representative to the association, who is called the chaplain, moderator, spiritual guardian, or assistant. An exception applies in the cases of Jewish and Evangelical-Augsburg associations, which don't provide for establishing such persons to be the association's link between the ecclesiastical and secular authorities. Both the ecclesiastical authority and the laity have the right to initiate the establishment of functional denominational associations (the exceptions being the Adventist associations

28 Journal of Laws [Dziennik Ustaw] of 1989 No. 29, item 155 as amended (consolidated text: Journal of Laws [Dziennik Ustaw] of 2017, item 1153).

29 Journal of Laws [Dziennik Ustaw] of 1989 No. 29, item 154 as amended (consolidated text: Journal of Laws [Dziennik Ustaw] of 2013, item 1169).

30 Journal of Laws [Dziennik Ustaw] of 1991 No. 66, item 287 as amended (consolidated text: Journal of Laws [Dziennik Ustaw] of 2014, item 1726).

31 Journal of Laws [Dziennik Ustaw] of 1994 No. 73, item 324 as amended (consolidated text: Journal of Laws [Dziennik Ustaw] of 2015, item 483).

32 Journal of Laws [Dziennik Ustaw] of 1994 No. 73, item 323 as amended (consolidated text: Journal of Laws [Dziennik Ustaw] of 2015, item 43).

33 Journal of Laws [Dziennik Ustaw] of 1995 No. 97, item 479 as amended (consolidated text: Journal of Laws [Dziennik Ustaw] of 2014, item 1712).

34 Journal of Laws [Dziennik Ustaw] of 1997 No. 41, item 253 as amended (consolidated text: Journal of Laws [Dziennik Ustaw] of 2015, item 14).

35 Journal of Laws [Dziennik Ustaw] of 1997 No. 41, item 252 as amended (consolidated text: Journal of Laws [Dziennik Ustaw] of 2015, item 44).

36 Journal of Laws [Dziennik Ustaw] of 1995 No. 97, item 482 as amended (consolidated text: Journal of Laws [Dziennik Ustaw] of 2014, item 1599).

37 Journal of Laws [Dziennik Ustaw] of 1995 No. 97, item 481 as amended (consolidated text: Journal of Laws [Dziennik Ustaw] of 2014, item 1889).

38 Journal of Laws [Dziennik Ustaw] of 1995 No. 97, item 480 as amended (consolidated text: Journal of Laws [Dziennik Ustaw] of 2015, item 169).

39 Journal of Laws [Dziennik Ustaw] of 1997 No. 41, item 251 as amended (consolidated text: Journal of Laws [Dziennik Ustaw] of 2014, item 1798).

40 Journal of Laws [Dziennik Ustaw] of 1997 No. 41, item 254 as amended (consolidated text: Journal of Laws [Dziennik Ustaw] of 2015, item 13). 
which can only be created by the church authority). The objectives of those associations are primarily charitable, educational, scientific, and service activities. An exception applies to Jewish associations that are created especially to promote Jewish culture and tradition. The Law on Associations of 1989 applies to denominational associations, hence, they may be created either as ordinary or as registered associations, but there are exceptions. First of all, in the case of withdrawal of approval by the church authority. In such cases the Catholic, Baptist, Pentecostal, and Adventist associations, and orthodox brotherhoods lose their character of denominational associations and become secular associations, which means that they subsequently fall fully under the authority and provisions of the Law on Associations. Moreover, the church authority may not request the changing of the name of the association. In the cases of Jewish and Evangelical-Augsburg associations the withdrawal of the approval of the church authority involves the right to recourse to the court to dissolve the association. The second exception concerns the dissolution of an association - the specified governmental authorities can't apply to the court to dissolve the association without previous consultation with designated church authorities. The form of consultation differs depending on the regulation under which the association is established, and it will take the form of either agreement between church and state authorities or an opinion issued by the church authorities. The third exception concerns the assets of the liquidated association, which become the property of a hierarchically higher ecclesial legal person. ${ }^{41}$

The creating of a second kind of association - the ecclesiastical association - is mentioned in six individual acts regulating the legal status of the Catholic Church, the Orthodox Church in Poland, the Evangelical Methodist Church, the Old Catholic Mariavite Church, the Catholic Mariavite Church, and the Polish National Catholic Church. The main purpose of these organizations is the implementation of the mission of the churches they represent. The Law on Associations does not apply to those associations. The right to create this kind of associations is given to church authorities. In some cases associations established through this procedure may be granted legal personality by regulation of the minister responsible for denominational affairs. In the Catholic and Orthodox churches, ecclesiastical associations may be created also on the initiative of the laity with the approval and involvement of competent church authorities. However, the associations established through this procedure do not qualify for legal personality. ${ }^{42}$

It must be said, that ecclesiastical associations may be created not only by the churches and other denominations having individual regulatory laws, but by all churches and other denominations legally existing in Poland as well. That is to say, it is possible for all the churches and other denominations registered in the Register of churches and other denominations, maintained by the Minister of Interior and Administration. Today, 165 independent churches and other denominations are entered in the Register in sec-

41 For more see: A. Mezglewski, Stowarzyszenia wyznaniowe [in:] A. Mezglewski, H. Misztal, P. Stanisz, Prawo wyznaniowe, Lublin 2011, pp. 101-105; K. Krzysztofek, Hasło: Stowarzyszenia wyznaniowe [in:] A. Mezglewski (ed.), Leksykon prawa wyznaniowego. 100 podstawowych pojęć, Warszawa 2014, pp. 427-433.

42 See: A. Mezglewski, Organizacje kościelne [in:] A. Mezglewski, H. Misztal, P. Stanisz, Prawo wyznaniowe, Lublin 2011, pp. 105-107; K. Krzysztofek, Hasło: Organizacje kościelne [in:] A. Mezglewski (ed.), Leksykon prawa wyznaniowego. 100 podstawowych pojęć, Warszawa 2014, pp. 257-259. 
tion $\mathrm{A}$, and 5 interchurch organizations are entered in section $\mathrm{B}{ }^{43} \mathrm{All}$ of these churches and other denominations are subject to their own statutes, as well as to the Law on the Guarantees of Freedom of Conscience and Religion of 1989. In connection with Article 37, Article 19 paragraph 2 point 14 guarantees those organizations the right to form ecclesiastical associations.

The third kind of associations are secular ones. The rules for their establishment are enumerated in the Law on the Guarantees of Freedom of Conscience and Religion of 1989 in article 2 point 11, which grants right to associate in secular organizations for the accomplishment of religious purposes. The Law on Associations remains totally applicable towards associations which have religious aims, but nonetheless remain outside the structures of churches and other denominations. Catholic associations, which can be created on the basis of article 37 of the law regulating the situation of the Catholic Church in Poland, are similar. Their creation is based on religious inspiration, they unite Catholics in mutual activities, and they promote Christian ideas, but they are established on the basis of the Law on Associations.

\section{Activities of religious associations in Poland}

The character of the activities of organizations established by the churches and other denominations along with those merely endorsed by them hasn't changed since the interwar period. The principal activities of ecclesiastical associations involve religious instruction and the organization of worship. Whereas those of the denominational associations would be more oriented toward some form of social benefit. This ensues from the fact that the people are identifiable as being both among the faithful while at the same time being citizens, so both the state and the churches have an interest in their well-being.

In the interwar period religious associations, especially those created by the Catholic Church - the largest and most populous church in Poland - focused on charitable activities. The newly reborn Polish state needed a huge expenditure of both human energy and material resources to provide for the needs of the large numbers of poor people, unemployed, veterans, orphans, and war widows. At that time the state didn't have enough financial or material resources to be able to help in a measure that would have been sufficient to meet the need. This is why religious associations which were created both as ecclesiastical associations ${ }^{44}$ and denominational associations in today's meaning played

43 The Register of churches and other denominations is available via internet at: https://mswia.gov.pl/ pl/wyznania-i-mniejszosci/relacje-panstwa-z-kosci/13964,Relacje-panstwa-z-Kosciolami-przydatne-informacje-dokumenty-i-akty-prawne.html (access: 14.04.2017).

44 During the interwar period the sodality movement was very popular in the Catholic Church. Sodalities were organizations acting mainly for the purpose of the spiritual development of theirs members, who regarded the Holy Mother with especially great respect. J. Harrasser, Katechizm Sodalicyjny - podręcznik dla Zarzadów Sodalicyj Marjańskich i do pouczania kandydatów, thum. D. Ziarniak, Poznań 1934; F. Kwiatkowski, Sodalicje Marjańskie w stużbie Kościoła, Kraków 1935; J. Rostworowski, Przewodnik Sodalicyj Mariańskich złączonych kanonicznie z archisodalicja Rzymska Prima Primaria, Kraków 1925. See more about sodalities in Krakow in 1918-1939: K. Krzysztofek, Sodalicja Mariańska Akademików w Krakowie w latach 1891-1953, "Czasopismo Prawno-Historyczne” 2013, Y. LXV, Issue 1, Poznań, pp. 423-441; idem, 
such a large role. Being the largest church, the Catholic Church in particular, supported the state in helping those in need.

The situation in Krakow in the interwar period, where many of the organizations providing assistance were inspired by the Catholic Church, presents a good example. These associations provided a wide range of support by operating institutions for people in need, such as the many social care homes, nurseries, orphanages, hospitals, and night shelters, and the kitchens where poor people could count on a free meal. ${ }^{45}$ Some associations didn't run institutions but helped in a different way by distributing food, clothes, or fuel. Some of the associations established during the interwar period, such as Caritas or Catholic Action, are still in existence. The roots of both of them date back to the Polish Second Republic.

In the context of charitable activities Caritas, which was created in particular Polish dioceses in the thirties (the initiator of the creation of Caritas in Krakow was bishop, and then cardinal, Adam Stefan Sapieha ${ }^{46}$ ), merits special attention. Caritas was created in response to a huge need in post-war Poland. Its task was to organize the charitable activities led by the Catholic Church in each diocese. Unfortunately, Caritas did not have sufficient time to fully develop its mission before the outbreak of the Second World War. It was reborn after the war, but in 1950 the Communist authorities liquidated it as a church charitable organization. ${ }^{47}$ It returned to its ecclesiastical roots in 1990, and today Caritas Poland and the various diocesan Caritas organizations are the successors of the Caritas that existed in the interwar period. ${ }^{48}$ The needs that must be satisfied by Caritas and other ecclesiastical and denominational associations ${ }^{49}$ today may be smaller than those of the interwar period, but it doesn't mean that they don't exist. Now, the state is more capable of dealing independently with social assistance, but it is certain that the charitable and social missions of the activities of institutions and establishments governed by churches provide a significant measure of support. Article 25 paragraph 3 of the Polish constitution of 1997 establishes the principle of cooperation between the state and churches or

Sodalicje mężczyzn w Krakowie na przełomie XIX i XX w., "Studia z Prawa Wyznaniowego" 2013, Vol. 16, Lublin, pp. 137-160; idem, Kongregacja Pań Dzieci Marii pod wezwaniem Matki Boskiej Częstochowskiej w Krakowie jako przyktad działalności prospotecznej w Krakowie w okresie międzywojennym [in:] W. Uruszczak, K. Krzysztofek, M. Mikuła (eds.), Kościoly i inne zwiazki wyznaniowe w stużbie dobru wspólnemu, Kraków 2014, pp. 301-319; idem, Organizacja Sodalicji Mariańskiej Studentek Uniwersytetu Jagiellońskiego w Krakowie (1906-1939), "Krakowskie Studia z Historii Państwa i Prawa" 2014, Vol. 7, Part A, Issue 2, Kraków, pp. 273-286.

45 For more about the activities of Catholic associations in Krakow between 1918 and 1939 see: B. Panek, Krakowskie organizacje charytatywne w latach 1918-1939, Kraków 1986; K. Krzysztofek, Stowarzyszenia katolickie...

46 Caritas w Krakowie, "Ruch Charytatywny" 1934, Yearbook XIII, pp. 87-88.

47 For more see: A. Szymański, Przejęcie kościelnej organizacji charytatywnej „Caritas” przez władze ludowa w $1950 r$. [in:] W. Uruszczak, K. Krzysztofek, M. Mikuła (eds.), Kościoły i inne zwiazki wyznaniowe w stużbie dobru wspólnemu, Kraków 2014, pp. 321-333.

48 For more about Caritas currently, see: http://www.caritas.pl/o-nas-2/ (access: 01.04.2016).

49 There are for example: the Christian Charity Association (Chrześcijańskie Stowarzyszenie Dobroczynne), which is a pentacostal organization (http://chsd.pl/download/STATUT\%20nowy.pdf [access: 01.04.2016]); evangelic associations (J. Szturc, Stowarzyszenia spoleczno-kulturalne w polskim ewangelicyzmie, Warszawa 2006); Jewish associations (http://www.izrael.badacz.org/zydzi_w_polsce/org.html [access: 01.04.2016]); and Catholic associations (A. Petrowa-Wasilewicz, Leksykon ruchów i stowarzyszeń w Kościele (ruchy, stowarzyszenia, III zakony, bractwa), Warszawa 2000). 
other denominations for the good of man and for the common good. The activities of the numerous charitable organizations created at the initiative of churches and other denominations ${ }^{50}$ provide a good example of the implementation of this provision.

\section{Conclusion}

The freedom of conscience and religion together with the freedom to create associations were guaranteed in the interwar period and are guaranteed nowadays. What is important - those freedoms were introduced into the constitutions of 1921, 1935 and currently binding constitution of 1997 . That means that the state authorities appreciate the importance of those rights. Unfortunately, in the interwar time in Poland over ten years after regaining independence were still in force post-partition law on associations. That's why it was difficult to create associations that might have existed in all Polish territory, because each part of Poland (former Prussian, Austrian or Russian partition sector) had different requirements to create association. The unification of law on associations was made in 1932 by the Law on Associations. Since that time it was clear how to create associations, without matter in what part of Poland they will have been acting. But that Act excluded those associations that were created by the legally approved churches and other denominations and only for the religious purposes. The Regulation of 1934 expanded the catalogue of the associations that weren't subject of the Law on Associations of 1932 they were called the associations designed exclusively for the religious purposes of the Catholic Church. It must be said that today's Law on Association of 1989 also excludes from the application churches and other denominations, their legal entities, and some religious associations. But nowadays we may different three kinds of associations that are created because of religious purposes - ecclesiastical, denominational and secular associations established for religious purposes. They can't be identified with those from the interwar period. But it doesn't mean that because of amendment of the law the previous associations were liquidated. Many of those that were existed between 1918-1939 and weren't liquidated in the period of Polish People's Republic are acting now like for example: Caritas, Catholic Action or Sodalities. The reason of their existence is current. Providing support for people in need, and generosity not only in the material context, are attributes inscribed in the missions of many churches and other denominations, and refer to the churches as well as to their membership. On the one hand the right to establish associations for religious purposes is an entitlement, but on the other hand it is also obligation. That's why it is worth mentioning that the existence and activities of those associations both in the past and nowadays wouldn't be possible without the engagement of the faithful, who join the associations to help others by dedicating their time

50 See for example: J. Bar, Kościót w życiu publicznym na przykładzie zaangażowania w pomoc spoteczna i działalność charytatywna w archidiecezji przemyskiej [in:] A. Mezglewski (ed.), Funkcje publiczne zwiazków wyznaniowych, Lublin 2007, pp. 203-229; J. Krzywkowska, A. Bitowt, Rola kościołów i innych zwiazków wyznaniowych $w$ umacnianiu rodziny na obszarze województwa warmińsko-mazurskiego [in:] W. Uruszczak, K. Krzysztofek, M. Mikuła (eds.), Kościoły i inne związki wyznaniowe w stużbie dobru wspólnemu, Kraków 2014, pp. 145-157. 
and energy. Without both their material and spiritual assistance, as well as the time and attention they devote to people in need, the activities of many religious associations wouldn't be possible.

\section{Bibliography}

Bar J., Kościół w życiu publicznym na przykładzie zaangażowania w pomoc społeczna i działalność charytatywna w archidiecezji przemyskiej [in:] A. Mezglewski (ed.), Funkcje publiczne związków wyznaniowych, Lublin 2007.

Bączkowicz F., Prawo kanoniczne, podręcznik dla duchowieństwa, Vol. I, Opole 1957.

Caritas w Krakowie, "Ruch Charytatywny" 1934, Yearbook XIII.

Grabowski I., Prawo kanoniczne wedtug nowego kodeksu, Lwów 1927.

Harrasser J., Katechizm Sodalicyjny - podręcznik dla Zarządów Sodalicyj Marjańskich i do pouczania kandydatów, tłum. D. Ziarniak, Poznań 1934.

Krukowski J., Stowarzyszenia wiernych chrześcijan [in:] J. Dyduch, W. Góralski, E. Górecki, J. Krukowski, M. Sitarz, Komentarz do Kodeksu Prawa Kanonicznego, Vol. II/1, Lud Boży, Pallottinum 2005.

Krzysztofek K., Hasło: Organizacje kościelne [in:] A. Mezglewski (ed.), Leksykon prawa wyznaniowego. 100 podstawowych pojęć, Warszawa 2014.

Krzysztofek K., Hasto: Stowarzyszenia wyznaniowe [in:] A. Mezglewski (ed.), Leksykon prawa wyznaniowego. 100 podstawowych pojęć, Warszawa 2014.

Krzysztofek K., Kongregacja Pań Dzieci Marii pod wezwaniem Matki Boskiej Czestochowskiej w Krakowie jako przykład działalności prospołecznej w Krakowie w okresie międzywojennym [in:] W. Uruszczak, K. Krzysztofek, M. Mikuła (eds.), Kościoły i inne związki wyznaniowe w stużbie dobru wspólnemu, Kraków 2014.

Krzysztofek K., Organizacja Sodalicji Mariańskiej Studentek Uniwersytetu Jagiellońskiego w Krakowie (1906-1939), "Krakowskie Studia z Historii Państwa i Prawa" 2014, Vol. 7, part A, Issue 2, Kraków.

Krzysztofek K., Sodalicja Mariańska Akademików w Krakowie w latach 1891-1953, “Czasopismo Prawno-Historyczne” 2013, Vol. LXV, Issue 1, Poznań.

Krzysztofek K., Sodalicje mężczyzn w Krakowie na przetomie XIX i XX w., "Studia z Prawa Wyznaniowego" 2013, Vol. 16, Lublin.

Krzysztofek K., Stowarzyszenia katolickie w Krakowie w latach 1918-1939. Studium historycznoprawne, Kraków 2014.

Krzysztofek K., Stowarzyszenia Kościoła Katolickiego w świetle norm prawa polskiego i prawa kanonicznego [in:] D. Walencik (ed.), Prawo wyznaniowe w Polsce (1989-2009). Analizy dyskusje - postulaty, Katowice-Bielsko-Biała 2009.

Krzywkowska J., Bitowt A., Rola kościołów i innych związków wyznaniowych w umacnianiu rodziny na obszarze województwa warmińsko-mazurskiego [in:] W. Uruszczak, K. Krzysztofek, M. Mikuła (eds.), Kościoły i inne związki wyznaniowe w stużbie dobru wspólnemu, Kraków 2014.

Kwiatkowski F., Sodalicje Marjańskie w stużbie Kościoła, Kraków 1935.

Langrod J.S., Polskie prawo o stowarzyszeniach; uwagi krytyczne, Kraków 1934.

Łukomski S., Konkordat zawarty dnia 10 lutego 1925 r. pomiędzy Stolicą Apostolska a Rzeczapospolita Polska, Łomża 1934.

Mezglewski A., Organizacje kościelne [in:] A. Mezglewski, H. Misztal, P. Stanisz, Prawo wyznaniowe, Lublin 2011.

Artykuły - Articles 
Mezglewski A., Stowarzyszenia wyznaniowe [in:] A. Mezglewski, H. Misztal, P. Stanisz, Prawo wyznaniowe, Lublin 2011.

Misztal H., Historia relacji państwo - Kościół w Polsce [in:] A. Mezglewski, H. Misztal, P. Stanisz, Prawo wyznaniowe, Warszawa 2011.

Ordon M., Bezprawne przejęcie przez władze komunistyczne majątku Stowarzyszenia "Opieka nad Dziewczętami pod wezwaniem św. Józefa” w Krakowie, "Studia z Prawa Wyznaniowego" 2001, Vol. 2.

Ordon M., Modification of the legal basis of the activity of religious orders in Poland introduced by the communist authorities in 1949, "Studia z Prawa Wyznaniowego" 2014, Vol. 17.

Ordon M., Ograniczenia wolności zrzeszania się w odniesieniu do organizacji Kościoła katolickiego w Polsce Ludowej [in:] E. Kozerska, P. Sadowski, A. Szymański (eds.), Idea wolności w ujęciu historycznym i prawnym. Wybrane zagadnienia, Toruń 2010, pp. 143-154.

Ordon M., Prawo o stowarzyszeniach jako instrument antykościelnej polityki władz komunistycznych w okresie Polski Ludowej - zarys problemu, "Studia z Prawa Wyznaniowego" 2002, Vol. 4.

Panek B., Krakowskie organizacje charytatywne w latach 1918-1939, Kraków 1986.

Petrowa-Wasilewicz A., Leksykon ruchów i stowarzyszeń w Kościele (ruchy, stowarzyszenia, III zakony, bractwa), Warszawa 2000.

Piwocki J., Stesłowicz W., Münz J., Zbiór ustaw i rozporządzeń administracyjnych, t. I, Lwów 1909.

Rostworowski J., Przewodnik Sodalicyj Mariańskich złączonych kanonicznie z archisodalicja Rzymską Prima Primaria, Kraków 1925.

Sarnecki P., Prawo o stowarzyszeniach. Komentarz, ed. II, Zakamycze 2002.

Smoktunowicz E., Prawo zrzeszania się w Polsce, Warszawa 1992.

Suski P., Stowarzyszenia i fundacje, Warszawa 2005.

Szturc J., Stowarzyszenia społeczno-kulturalne w polskim ewangelicyzmie, Warszawa 2006.

Szymaniak A., Prawa obywatelskie w konstytucjach z 1952 r. i 1997 r. Analiza porównawcza, "Ruch prawniczy, ekonomiczny i socjologiczny" 2001, Y. LXIII, Vol. 3.

Szymański A., Przejęcie kościelnej organizacji charytatywnej „Caritas” przez władze ludowa w 1950 r. [in:] W. Uruszczak, K. Krzysztofek, M. Mikuła (eds.), Kościoły i inne zwiazki wyznaniowe w stużbie dobru wspólnemu, Kraków 2014.

Szypuliński S., Prawo o stowarzyszeniach, Poznań 1997.

\section{Internet sources}

http://www.caritas.pl/o-nas-2/ (access: 01.04.2016).

http://chsd.pl/download/STATUT\%20nowy.pdf (access: 01.04.2016).

http://www.izrael.badacz.org/zydzi_w_polsce/org.html (access: 01.04.2016).

https://mswia.gov.pl/pl/wyznania-i-mniejszosci/relacje-panstwa-z-kosci/13964,Relacje-panstwaz-Kosciolami-przydatne-informacje-dokumenty-i-akty-prawne.html (access: 14.04.2017).

\section{Legal sources}

The Constitution of the Republic of Poland of $17^{\text {th }}$ March 1921, Journal of Laws [Dziennik Ustaw] No. 44, item 267 as amended.

The Constitution of the Republic of Poland of $23^{\text {rd }}$ April 1935, Journal of Laws [Dziennik Ustaw] No. 30, item 227. 
The Constitution of the Polish People's Republic of $22^{\text {nd }}$ July 1952, Journal of Laws [Dziennik Ustaw] No. 33, item 232, as amended (consolidated text: Journal of Laws [Dziennik Ustaw] of 1976, No. 7, item 36).

The Constitution of the Republic of Poland of $2^{\text {nd }}$ April 1997, Journal of Laws [Dziennik Ustaw] No. 78, item 483 as amended.

Concordat between the Holy See and the Republic of Poland concluded on $10^{\text {th }}$ February 1925 , Journal of Laws [Dziennik Ustaw] No. 72, item 501.

Concordat between the Holy See and the Republic of Poland concluded on $28^{\text {th }}$ July 1993, Journal of Laws [Dziennik Ustaw] of 1998 No. 51, item 318.

Law of $14^{\text {th }}$ October 1927 regulating the legal situation of the Jewish Communities, Journal of Laws [Dziennik Ustaw] No. 91, item 818 (consolidated text: Journal of Laws [Dziennik Ustaw] of 1928 No. 52, item 500).

Law of $22^{\text {nd }}$ March 1928 regulating the legal situation of the non-hierarchical Eastern Old Believers' Church, Journal of Laws [Dziennik Ustaw] No. 38, item 363.

Law of $27^{\text {th }}$ October 1932 - The Law on Associations, Journal of Laws [Dziennik Ustaw] No. 94, item 808 as amended.

Law of $21^{\text {st }}$ April 1936 regulating the legal situation of the Karaim Religious Union, Journal of Laws [Dziennik Ustaw] No. 30, item 241.

Law of $21^{\text {st }}$ April 1936 regulating the legal situation of the Muslim Religious Union, Journal of Laws [Dziennik Ustaw] No. 30, item 240.

Law of $25^{\text {th }}$ November 1936 regulating the legal situation of the Evangelical Church of the Augsburg Confession, Journal of Laws [Dziennik Ustaw] No. 88, item 613.

Law of $18^{\text {th }}$ November 1938 regulating the legal situation of the Orthodox Church in Poland, Journal of Laws [Dziennik Ustaw] No. 88, item 597.

Law of $7^{\text {th }}$ April 1989 - The Law on Associations, Journal of Laws [Dziennik Ustaw] No. 20, item 104 as amended (consolidated text: Journal of Laws [Dziennik Ustaw] of 2017, item 210).

Law of $17^{\text {th }}$ May 1989 - The Law of the Guarantees of Freedom of Conscience and Religion, Journal of Laws [Dziennik Ustaw] No. 29, item 155 as amended (consolidated text: Journal of Laws [Dziennik Ustaw] of 2017, item 1153).

Law of $17^{\text {th }}$ May 1989 regulating the legal situation of the Catholic Church in the Republic of Poland, Journal of Laws [Dziennik Ustaw] No. 29, item 154 as amended (consolidated text: Journal of Laws [Dziennik Ustaw] of 2013, item 1169).

Law of $4^{\text {th }}$ July 1991 regulating the legal situation of the Orthodox Church in Poland, Journal of Laws [Dziennik Ustaw] No. 66, item 287 as amended (consolidated text: Journal of Laws [Dziennik Ustaw] of 2014, item 1726).

Law of $13^{\text {th }}$ May 1994 regulating the legal situation of the Evangelical Reformed Church in the Republic of Poland, Journal of Laws [Dziennik Ustaw] No. 73, item 324 as amended (consolidated text: Journal of Laws [Dziennik Ustaw] of 2015, item 483).

Law of $13^{\text {th }}$ May 1994 regulating the legal situation of the Evangelical Church of the Augsburg Confession in the Republic of Poland, Journal of Laws [Dziennik Ustaw] No. 73, item 323 as amended (consolidated text: Journal of Laws [Dziennik Ustaw] of 2015, item 43).

Law of $30^{\text {th }}$ June 1995 regulating the legal situation of the Evangelical Methodist Church in the Republic of Poland, Journal of Laws [Dziennik Ustaw] No. 97, item 479 as amended (consolidated text: Journal of Laws [Dziennik Ustaw] of 2014, item 1712).

Law of $30^{\text {th }}$ June 1995 regulating the legal situation of the Polish National Catholic Church in the Republic of Poland, Journal of Laws [Dziennik Ustaw] No. 97, item 482 as amended (consolidated text: Journal of Laws [Dziennik Ustaw] of 2014, item 1599).

Law of $30^{\text {th }}$ June 1995 regulating the legal situation of the Seventh Day Adventist Church in the Republic of Poland, Journal of Laws [Dziennik Ustaw] No. 97, item 481 as amended (consolidated text: Journal of Laws [Dziennik Ustaw] of 2014, item 1889). 
Law of $30^{\text {th }}$ June 1995 regulating the legal situation of the Baptist Church in the Republic of Poland, Journal of Laws [Dziennik Ustaw] No. 97, item 480 as amended (consolidated text: Journal of Laws [Dziennik Ustaw] of 2015, item 169).

Law of $20^{\text {th }}$ February 1997 regulating the legal situation of the Old Catholic Mariavite Church in the Republic of Poland, Journal of Laws [Dziennik Ustaw] No. 41, item 253 as amended (consolidated text: Journal of Laws [Dziennik Ustaw] of 2015, item 14).

Law of $20^{\text {th }}$ February 1997 regulating the legal situation of the Catholic Mariavite Church in the Republic of Poland, Journal of Laws [Dziennik Ustaw] No. 41, item 252 as amended (consolidated text: Journal of Laws [Dziennik Ustaw] of 2015, item 44).

Law of $20^{\text {th }}$ February 1997 regulating the legal situation of the Union of Jewish Religious Communities in the Republic of Poland, Journal of Laws [Dziennik Ustaw] No. 41, item 251 as amended (consolidated text: Journal of Laws [Dziennik Ustaw] of 2014, item 1798).

Law of $20^{\text {th }}$ February 1997 regulating the legal situation of the Pentecostal Church in the Republic of Poland, Journal of Laws [Dziennik Ustaw] No. 41, item 254 as amended (consolidated text: Journal of Laws [Dziennik Ustaw] of 2015, item 13).

The Regulation of $28^{\text {th }}$ January 1934 of the Council of Ministers about the associations designed exclusively for the religious purposes of the Catholic Church, Journal of Laws [Dziennik Ustaw] No. 9, item 72.

The regulation of $10^{\text {th }}$ December 1938 of the Council of Ministers - Internal Statute of the Orthodox Church in Poland, Journal of Laws [Dziennik Ustaw] No. 103, item 679.

\section{Streszczenie}

\section{Podstawy prawne istnienia stowarzyszeń religijnych w Polsce w okresie między- wojennym i współcześnie oraz przykłady ich działalności}

Po I wojnie światowej odrodzone państwo polskie potrzebowało wielkich nakładów finansowych, aby poradzić sobie z ogromem biedy, bezrobocia i potrzeb. Ponieważ nie było w stanie samo nieść wsparcia potrzebującym, powstawały liczne organizacje dobroczynne tworzone bądź przez wiernych z inspiracji religijnej, bądź wprost przez Kościoły i związki wyznaniowe. Najliczniejszą grupę stanowiły te zakładane przez Kościół katolicki - największy związek wyznaniowy w ówczesnej Polsce. Podstawą do tworzenia stowarzyszeń w dwudziestoleciu międzywojennym w Polsce było prawo o stowarzyszeniach z 1932 roku. Wcześniej, przed 1932 rokiem, prawo to było realizowane na podstawie partykularnych norm pozaborczych. Jednakże prawo o stowarzyszeniach w dużej mierze nie znajdowało zastosowania do stowarzyszeń religijnych. Dziś prawo do tworzenia stowarzyszeń w Polsce opiera się na ustawie z 1989 roku Prawo o stowarzyszeniach, która rozróżnia stowarzyszenia zarejestrowane i niezarejestrowane. Ale ustawę stosuje się w pełni tylko do stowarzyszeń o celach religijnych, stowarzyszeń świeckich, do stowarzyszeń wyznaniowych natomiast - z wyjątkami, a do stowarzyszeń kościelnych nie znajduje w ogóle zastosowania. Współcześnie, podobnie jak w okresie dwudziestolecia międzywojennego, cel działania wymienionych grup stowarzyszeń pozostaje niezmienny - tym celem jest przede wszystkim działalność dobroczynna i charytatywna.

Słowa klucze: dwudziestolecie międzywojenne, prawo o stowarzyszeniach, stowarzyszenia wyznaniowe, organizacje kościelne, Kościoły i inne związki wyznaniowe. 